\title{
Yoksulluğun Kavramsal Çerçevesi İçinde KADIN $^{1}$
}

\section{WOMAN within The Conceptual Framework of Poverty}

\author{
Doç. Dr. Gökçen SAYAR ÖZKAN²
}

Öz

$\mathrm{Y}$ oksulluk, hem ekonomik hem de sosyolojik faktörleri barındıran bir kavram olması nedeniyle yoksulluk olgusu içinde çoğu zaman sosyal dışlanma, işsizlik, eşitsizlik, cinsiyet vb. etkiler de gözlemlenmektedir. Cinsiyet ayrımcılığının yoksulluğu çoğu zaman beslemesi, 1995 yılında IV. Dünya Kadın Konferansı Eylem planında "yoksulluğun kadınlaşması" ifadesinin yer almasına neden olmuştur. Günümüzde dünyada yoksulluk oranı içerisinde yer alan insanların \%70'inin kadın olması; yoksulluk ve kadın kavramının birlikte ele alınması gerekliliğini ortaya koymaktadır. $\mathrm{Bu}$ durum gerek yoksulluğun azaltılmasinda gerekse toplumsal cinsiyet adaletinin gerçekleşmesinde katkı sağlayacaktır. Bu çalışmada yoksulluk kavramı ve türleri kavramsal olarak irdelenerek, kadınların yoksulluk içinde payı ve önemi tespit edilerek hem yoksulluğun azaltılması hem de toplumsal cinsiyet adaletinin gerçekleşmesi için çeşitli çözüm önerileri sunulmaya çalışılacaktır.

Anahtar Kelimeler: Yoksulluk, Kadın Yoksulluğu, Kadın Girişimciliği, Mikro Kredi

\section{Abstract}

$\mathrm{B}$ ecause poverty is a concept including both economic and sociological factors, effects like unemployment, gender inequality, social exclusion usually go hand in hand. Since gender inequality usually leads to poverty, the phrase "feminization of poverty" is included in 1995 at the 4th World Conference on Women action plan. Today, the rate of women who are at or under the poverty line is $70 \%$; that reveals the necessity of dealing with women and poverty with together. That will contribute to poverty reduction and the realization of gender justice. This study examines poverty

\footnotetext{
1 Bu makale, aynı isimle 03.03.2016 tarihinde KADEM tarafından düzenlenen II. Toplumsal Cinsiyet Adaleti Kongresi’nde sunulan bildirinin gözden geçirilmiş şeklidir.

2 Gaziantep Üniversitesi İİBF Fakültesi İktisat Bölümü, ozkang@gantep.edu.trtt 
concepts and types and try to offer various solutions for the realization of both gender justice and poverty reduction.

Key Words: Poverty, Woman, Feminization of Poverty

\section{Giriş}

Yoksulluk gerek tanımlanması gerekse ölçülmesi bakımından sürekli tartışmalara, yeni kavramlara ve ölçütlere ihtiyaç duyulan bir kavramdır. Yoksulluk kelimesinin tanımlanmasındaki en önemli sorun yoksulluğun içinde yer alan kavramların toplumdan topluma, kişilere ve toplumsal kültüre bağlı olarak da değişmesinden kaynaklanır. 19. yy. sonlarında sanayi devriminin gerçekleşmesi ile birlikte artık yoksulluk bireysel bir kavram olmaktan öteye toplumsal bir kavram olma niteliği kazanmaya başlamıştır. Daha sonra hem dünyada hem de Türkiye'de özellikle 1980'li yıllardan sonra önemli bir kavram olmaya başlamıştır. Bu dönemde yoksulluk gerek hükümetlerin, gerekse de uluslararası kuruluşların ve sivil toplum örgütlerinin de öncelikli programlarında yer alan ve sosyal politikalarının belirlenmesinde öncelik kazanan bir unsur olmuştur (Yusufoğlu, 2010, s. 8-10).

Bu çalışmada öncelikli olarak yoksulluk kavramı, türleri ve Türkiye’de yoksulluğun durumu ve özellikle de yoksulluktan en fazla etkilenen kesimlerden kadınların yaşadığı yoksulluk açıklanmaya çalışılarak Türkiye’de kadınların yaşadığı yoksulluğa bağlı çözüm önerileri sunulmaya çalışılacaktır.

Çalışma 3 bölümden oluşmaktadır. İlk bölümde genel olarak yoksulluğun kavramsal çerçevesi çizilerek, yoksulluk türlerine değinilecektir. İkinci bölümde, Türkiye’de yoksulluğun ve kadının yoksulluk içerisindeki görünümü istatistikî verilerle incelenecektir. Son bölümde toplumsal cinsiyet adaletinin gerçekleşebilmesi için "yoksulluğun kadınlaşması" kavramına vurgu yapılmaya çalışılacaktır.

\section{Yoksulluk Kavramı}

Yoksulluk genel olarak bir halkın veya bir kısmının temel gereksinimlerini karşılayamaması ve kişilerin yaşamak için asgari düzeydeki yaşam standartlarına sahip olamamasıdır (Öztürk ve Çetin, 2009, s. 2661). Yoksulluk kavramının tek bir tanımının olmaması; hem içinde sosyolojik hem de ekonomik kavramlarını barındırması ve ölçütünün tek olmamasından kaynaklanır. Ayrıca "görelilik" içermesi de tanımlamayı zorlaştırmaktadır. Kime göre, neye göre, hangi kültürlere göre gibi soruların cevabı toplumdan topluma değişebildiği gibi bireyden bireye de değişiklik göstermektedir (Şener, 2009, s. 1). Yoksulluk beraberinde birçok ekonomik ve sosyolojik sorunu da beraberinde getirmektedir. Genel olarak işsizlik, sağlık sorunları, barınma, açlık, eğitim imkânlarına erişememe, toplumsal dışlanma bunların başında gelmektedir. 
Yoksulluk bugün sadece az gelişmiş ülkelerin değil, gelişmekte olan hatta gelişmiş ülkelerin de mücadele ettiği bir sorundur. Çünkü çoğu zaman ekonomik büyümeyi gerçekleştiren ülkeler de yoksulluğu önleyememektedir. Öyle ki bu durum bazen ekonomik büyümeyle birlikte artan bir yoksulluk şeklinde de olabilmektedir (Eren ve Bahar, 2004, s. 37).

\subsection{Yoksulluk Türleri}

\subsubsection{Mutlak Yoksulluk- Göreli Yoksulluk}

Mutlak yoksulluk ya da diğer adıyla birinci derecede yoksulluk, insan yaşamı için gerekli beslenme, barınma, giyinme gibi temel ihtiyaçları karşılayacak gelire sahip olamamayı ifade eder (Altan, 2004, s. 146). Bu durumda yoksulluk sınırı iki biçimde belirlenmektedir. Bunlardan ilki yoksulluğu gıda harcamalarına göre belirlerken ikincisi temel ihtiyaçların karşılanıp karşılanmamasına göre belirlemektedir. Gıda harcamaları için bir sepet maliyeti veya bir kişinin alması gereken günlük kalori miktarının gerektirdiği harcama miktarı hesaplanmaktadır. Bu durumda bu harcamaları karşılayamayan ve/veya günlük gerekli kalori miktarını alamayan kişi yoksul olarak kabul edilmektedir. Temel ihtiyaçların karşılanması yaklaşımında ise, gerekli olan gıda harcamalarına diğer temel ihtiyaçlar olan giyinme, barınma ve ısınma harcamaları eklenerek bu harcamaları karşılayacak gelir hesaplanmaktadır. Bu gelirin altında kalan kısım yoksul olarak kabul edilmektedir. Sadece gıda harcamalarına yönelik belirlenen harcama miktarı "açlık sınırı" olarak kabul edilirken diğer temel ihtiyaçları içine alarak belirlenen ise "yoksulluk sınırı" olarak kabul edilmektedir (Tokol ve Alper, 2015, s. 184). Bu durumda her ülke için, her bölge için hatta her il için farklı açlık sinırı ve yoksulluk sınırı oluşmaktadır. Dünya Bankası mutlak yoksulluk sınırını 1 ABD doları olarak belirlerken, Türkiye gibi Doğu Avrupa bölgelerini içeren ülkeler için 4 ABD doları, gelişmiş ülkeler için ise 14.40 ABD doları olarak belirlemiştir (Öztürk ve Çetin, 2009, s. 2665). Ancak bu yoksulluk sınırı çoğu zaman yoksulluğu doğru anlamak konusunda yeterli olamamaktadır. Bu noktadan hareketle yoksulluk açı̆̆1 kavramı yoksulluk sınırı altında kalan nüfusu belirlemek amacıyla ortaya çıkmıştır. Yoksulluk açığı; yoksulluk sınırı altında kalan kişilerin bu sınıra ulaşması için gerekli gelir miktarını hesaplamaktadır. Bu orandan hareketle de Yoksulluk Açı̆̆ı İndeksi hesaplanmaktadir (Uzun, 2003, s. 157).

Göreli Yoksulluk veya diğer adıyla Nispî Yoksulluk ise, “Temel ihtiyaçlarını mutlak olarak karşılayabilen ancak kişisel kaynaklarının yetersizliği sebebiyle toplumun genel refah seviyesinin altında kalan ve topluma sosyal olarak katılımları engellenmiş olan kişilerin yaşadığı yoksulluktur” (İncedal, 2013, s. 21). İnsanın sosyal bir varlık olmasından hareketle bireyin ve toplumun refah düzeyi belirleyici faktörler olmaktadır. Bu tanımdan yola çıkıldığında hemen hemen her toplumda yoksul insan olacaktır. Ancak gelişmiş ülkeler göreli yoksulluk yaşarken, gelişmekte olan ülkeler hem mutlak hem de göreli yoksulluk yaşamaktadır. Göreli yoksulluk hesaplanırken; öncelikle ortanca (medyan) gelirin belirli bir yüzdesinin (\%40-\%60) özellikle de \%50'sinin altında 
gelir elde edenler yoksul olarak adlandırılmaktadır (Tokol ve Alper, 2015, s. 185).

\subsubsection{Objektif Yoksulluk- Subjektif Yoksulluk}

Objektif yoksulluk ya da refah yaklaşımı yoksulluğun nedenlerini ve kişilerin yoksulluktan kurtulması için nelerin yapılması gerektiğini önceden belirlenip, değerlendirilmesidir. Subjektif ya da öznel yaklaşım ise daha çok kişilerin görüşlerine dayanarak, kişilerin kendilerini toplumda yoksul hissedip hissetmemesine dayanmaktadır. Diğer yaklaşımlardan farklı olarak kişinin kendisinin yoksul olup olmadığına inanmasıyla ilgilidir. Ancak uygulamada geniş kitleler ile görüşülmesi gerekliliği yaklaşımı zorlaştırmaktadır. Görüşmeler sonucunda ortalama bir gelir seviyesi tespit edilip, bu seviyenin altında kalan kesim yoksul kabul edilmektedir (Sam, 2008, s. 62).

\subsubsection{Gelir Yoksulluğu-İnsani Yoksulluk}

Önceden hesaplanmış asgari yaşam standartlarının sağlandığı yeterli gelir düzeyinin altında kalan hane halkları elde ettikleri gelire bağlı olarak yoksulluk sınırının altında ise; gelir yoksulu kabul edilmektedir (Doğan, 2014, s. 13).

Birleşmiş Milletler Kalkınma Programı (UNDP) tarafından ilki 1990 yılında hazırlanan insanî gelişme raporu kalkınmaya; sağlık, eğitim, bireysel özgürlük ve kadının konumu gibi yaşam kalitesini belirleyen faktörlerin etkisine dikkat çekmiştir. Çoğu zaman yaşam kalitesini ilgilendiren bu standartlar birlikte hareket etmektedir. ${ }^{3}$

1997 yılında yayımlanan İnsanî Gelişme Raporunda ise insanî yoksulluk kavramı yer almaktadır. Buna göre insanî yoksulluk; insanî gelişme, insanca yaşam için parasal imkânların yanı sıra temel gereksinimlerin karşılanması iktisadî ve sosyo-kültürel bazı imkânlara da sahip olmanın gerekliliğini de içermektedir. Buradan hareketle insanî yoksulluğu ölçmek için İnsanî Yoksulluk Endeksi geliştirilmiştir. Bu endeks;

- 40 yaşına kadar yaşam beklentisi olmayan nüfus oranı

- Okuma yazma bilmeyen yetişkinlerin oranı

- Sağlık hizmetlerine erişim olanağı olmayan nüfus

- Sağlıklı içme suyuna erişim olanağı olmayan nüfus

- Beş yaş altı düşük ağırlıklı çocuk sayısı

Verilerine dayanılarak oluşturulmaktadır (Gündoğan, 2008, s. 44).

3 http://issuu.com/undpturkiye/docs/name1d7344? $=4172436 / 2847987$ 


\subsubsection{Kirsal Yoksulluk- Kentsel Yoksulluk}

Kırsal ve kentsel yoksulluk, yoksulluk kavramının yoğunluğuna bağlı olarak mekânsal ifade edilen yoksulluktur. Kirsal yoksulluk genel olarak kalifiye olmayan kişilerin tarımsal üretimi gerçekleştirecek toprağa sahip olamamasıyla ortaya çıkan yoksulluktur. Kırda yaşanan bu yoksulluk iş bulma, daha iyi imkânlara kavuşma arzusuyla kente göç edilmesiyle kentsel yoksulluğa dönüşmektedir. Kırsal yoksulluğun kente göçü ile birlikte belirli kentlerde ve belirli semtlerde gelir eşitsizliği ve sosyal eşitsizlik de artmaktadır. Ayrıca bu kentlerde yaşanan yoğunluk kentin fonksiyonelliğini de bozarak, yetkinlik ve sosyal etkinliğini de bozmaktadır (Topgül, 2013, s. 282).

Kirsal yoksulluğun, kentsel yoksulluğun sonucu olduğuna dair tezler olduğu gibi, bu görüşü desteklemeyen tezler de bulunmaktadır. Destekleyen görüş, kırsal yoksulluğun kente itici güç olduğunu savunur. Ayrıca kent-kır kazanç farklılıklarının da göçe neden olan çekici güç olarak değerlendirmektedir (Buz, 2003, s. 156).

Yoksulluğun kente göçü engel olarak kabul ettiği ikinci görüş ise; kırsal yoksulluğun kentsel yoksulluğa neden olmadığının aksine yoksulluğun göçü kısıtlayan bir faktör olması durumu söz konusudur. Buna göre zaten düşük gelir seviyesine sahip olan kırsal yoksullar için göç bir maliyettir. Bu maliyeti karşılamak endişesi kırdan kente göçün önündeki engel olarak görülmektedir (Şenses, 2002, s. 161).

\subsubsection{Yapabilirlikten Yoksunluk}

1998 yılı Nobel Ödüllü Amartya Sen yoksulluğa yaklaşımıyla tüm dünyanın ve özelikle uluslararası kuruluşların yoksulluğa bakış açısını ve yoksulluğun nedenlerini tespit etmek yönündeki değerlendirmelerini değiştirmiştir. İnsanî gelişme ve insanî yoksulluk kavramları da Amartya Sen'e dayanmaktadır.

Sen’e göre kalkınma sadece GSMH artması, bireysel gelirdeki artış, sanayileşme, teknolojik ilerleme ile gerçekleştirilemez. Gerçekleştirilebilecek olsaydı bugün yaşanan iktisadî büyüme ve gelişmeye rağmen yoksulluk da artmazdı.

Sen’e göre günümüz kalkınma teorileri kişisel çıkarlara odaklanmıştır. Bireysel faydaların toplumsal faydayı sağlayacağı görüşüyle tek yanlı faydacı bir karakter taşımaktadır. Sen iktisadî, toplumsal ve siyasal etkinliklerin birbirlerini etkileyen birçok neden ve sonuç ilişkisine vurgu yaparak:

- İktisadî firsatlar

- Siyasal özgürlükler

- Toplumsal imkânlar

- Şeffaflık güvenceleri 
- Koruyucu güvenliği gibi 5 temel unsura dikkat çekmektedir. Sen’e göre kalkınma; insanların yararlandığı özgürlükleri genişletme süreci olarak değerlendirilmedir (Sen, 2004, s. 58 ).

Sen’e göre özgürlük kalkınma sürecinin merkezinde yer almaktadır. GSMH artışı, gelir artışı kalkınmada dolaylı katkı sağlar ancak bütünleyici katkı siyasal katılım özgürlüğü, temel eğitim alma, sağlık hizmetlerinden yararlanma fırsatının sağlanmasıyla gerçekleşecektir. Sen, siyasal özgürlüklerin (ifade ve seçme özgürlüğü) iktisadî güvenliği geliştirdiğine, toplumsal fırsatların (eğitim, sağlık) iktisadî katılımı sağlayarak, farklı türden özgürlüklerin birbirlerini destekleyerek kalkınma sürecinin gerçekleştirileceğini savunur (Sen, 2004, s. 76).

Sen'in yaklaşımı eşit hakların eşit yapılabilirlikler anlamına gelmediğini belirtmesi yoksulluğun önlenmesi bakımından da ayrı bir önem arz etmektedir. Sen’e göre yasa önünde kadınların erkeklerle eşit haklara sahip olması eşit başarı şansına sahip oldukları anlamına gelmemektedir. Yoksulluk çok boyutlu olduğundan (eğitim, azınlık gruba mensup olma, kadın olma, kapasite yoksunluğu vb.) yoksullukla mücadelede eşit hakların ötesinde özel düzenlemeler gerekmektedir ( Buğra, 2005, s. 7).

\section{Türkiye'de Yoksulluğun Görünümü ve Kadınların Yoksulluk İçindeki Profili}

TÜİK yoksulluğu "insanların temel ihtiyaçlarını karşılayamama" durumu olarak tanımlamaktadır. Yoksulluğu dar ve geniş anlamda olmak üzere iki türlü tanımlamak mümkündür. Dar anlamda yoksulluk, açlıktan ölme ve barınacak yeri olmama durumu iken, geniş anlamda yoksulluk, gıda, giyim ve barınma gibi olanakları yaşamlarını devam ettirmeye yettiği halde toplumun genel düzeyinin gerisinde kalmaktır. TÜİK yoksulluk hesaplamalarını hem gelire hem de harcama miktarını dikkate alarak hazırlamaktadır. 
Tablo 1. Eşdeğer hane halkı kullanılabilir fert gelirine göre hesaplanan yoksul sayıları, yoksulluk oranı ve yoksulluk açı̆̆ı, 2006-2014

\begin{tabular}{|c|c|c|c|c|c|c|c|c|c|}
\hline & \multicolumn{9}{|c|}{ Yillar } \\
\hline & 2006 & 2007 & 2008 & 2009 & 2010 & 2011 & 2012 & 2013 & 2014 \\
\hline \multicolumn{10}{|l|}{$\% 40-40 \%$} \\
\hline Yoksulluk Sinırı & 1881 & 2433 & 2531 & 2818 & 2972 & 3255 & 3611 & 4008 & 4443 \\
\hline $\begin{array}{l}\text { Yoksul Sayısı } \\
\text { (Bin Kişi) }\end{array}$ & 8665 & 6799 & 7021 & 7485 & 7355 & 7288 & 7344 & 6788 & 6572 \\
\hline Yoksulluk Oranı (\%) & 12,8 & 9,9 & 10,1 & 10,6 & 10,3 & 10,1 & 10,0 & 9,1 & 8,7 \\
\hline Yoksulluk Açı̆̆ğ(1) & 29,1 & 24,5 & 23,7 & 25,6 & 24,0 & 25,4 & 23,7 & 22,6 & 22,3 \\
\hline \multicolumn{10}{|l|}{$\% 50-50 \%$} \\
\hline Yoksulluk Sınırı & 2351 & 3041 & 3164 & 3522 & 3714 & 4069 & 4515 & 5007 & 5554 \\
\hline $\begin{array}{l}\text { Yoksul Sayısı } \\
\text { (Bin Kişi) }\end{array}$ & 12548 & 11163 & 11580 & 12097 & 12025 & 11670 & 11998 & 11137 & 11332 \\
\hline Yoksulluk Oranı (\%) & 18,6 & 16,3 & 16,7 & 17,1 & 16,9 & 16,1 & 16,3 & 15,0 & 15,0 \\
\hline Yoksulluk Açığı(1) & 31,7 & 26,4 & 25,6 & 28,0 & 26,6 & 26,3 & 26,9 & 26,0 & 24,4 \\
\hline \multicolumn{10}{|l|}{$\% 60-60 \%$} \\
\hline Yoksulluk Sinırı & 2821 & 3649 & 3797 & 4227 & 4457 & 4883 & 5418 & 6012 & 6665 \\
\hline $\begin{array}{l}\text { Yoksul Sayısı } \\
\text { (Bin Kişi) }\end{array}$ & 17165 & 16053 & 16714 & 17123 & 16963 & 16569 & 16741 & 16706 & 16501 \\
\hline Yoksulluk Oranı (\%) & 25,4 & 23,4 & 24,1 & 24,3 & 23,8 & 22,9 & 22,7 & 22,4 & 21,8 \\
\hline Yoksulluk Açı̆̆ı $(1)$ & 33,6 & 28,4 & 27,9 & 29,6 & 28,7 & 29,2 & 29,2 & 26,7 & 27,2 \\
\hline \multicolumn{10}{|l|}{$\% 70-70 \%$} \\
\hline Yoksulluk Sınırı & 3291 & 4257 & 4430 & 4931 & 5200 & 5697 & 6320 & 7016 & 7775 \\
\hline $\begin{array}{l}\text { Yoksul Sayısı } \\
\text { (Bin Kiși) }\end{array}$ & 21611 & 20595 & 21358 & 21938 & 21816 & 21730 & 22252 & 21979 & 22223 \\
\hline Yoksulluk Oranı (\%) & 32,0 & 30,1 & 30,9 & 31,1 & 30,6 & 30,0 & 30,2 & 29,5 & 29,4 \\
\hline Yoksulluk Açı̆̆ı(1) & 34,8 & 31,2 & 31,3 & 32,4 & 31,9 & 31,0 & 31,2 & 29,0 & 29,3 \\
\hline
\end{tabular}

TÜIK, Gelir ve Yaşam Koşulları Araştırması, 2006-2014 Gelirlerin referans dönemi bir önceki takvim yılıdır. (1) Yoksulluk açığı, yoksulluğun derecesi hakkında bilgi verir. Yoksulluk açığının 100'e yaklaşması, yoksulluğun derecesinin çok fazla olduğunu, küçülmesi ise yoksulluk risk derecelerinin daha az olduğunu ifade etmektedir.

Yoksulluk açığı $=((\text { Yoksulluk sınırı-Yoksulların EFB medyan geliri }) / \text { Yoksulluk sınırı })^{\star} 100$ formülüne göre hesaplanmıştır.

Tablo 1.den görülebileceği gibi 2006 yılından 2014 yılına kadar tüm yüzdelik dilimlerinde Türkiye'de yoksulluk oranı düşmüştür. Fert gelirleri yöntemine göre hesaplanan yoksulluk oranı \%40'lık oran için 2006 yılında \% 12.8' den 2014 yılına gelindiğinde \%8,7’ye düşmektedir. Yoksulluk riskini gösteren yoksulluk açığı ise yine aynı dilimde 2006 yılı için \%29,1 iken 2014 yılında bu oran \% 22.3’e düşmektedir. 
Tablo 2. Eşdeğer hane halkı kullanılabilir fert gelirine ve eğitim durumuna göre yoksulluk oranı, Türkiye, 2006-2014 (TÜİK, Gelir ve Yaşam Koşulları Araştırması, 20062014

\begin{tabular}{|c|c|c|c|c|c|c|}
\hline \multirow[b]{2}{*}{ Yillar } & \multirow{2}{*}{$\begin{array}{l}\text { Yoksulluk } \\
\text { riski }\end{array}$} & \multicolumn{5}{|c|}{ Yoksulluk Oranı (\%) } \\
\hline & & $\begin{array}{l}\text { Okur-yazar } \\
\text { olmayanlar }\end{array}$ & $\begin{array}{c}\text { Bir okul } \\
\text { bitirmeyenler }\end{array}$ & $\begin{array}{l}\text { Lise altı } \\
\text { eğitimliler }\end{array}$ & $\begin{array}{l}\text { Lise ve dengi } \\
\text { okul mezunları }\end{array}$ & $\begin{array}{l}\text { Yüksek öğre- } \\
\text { tim mezunları }\end{array}$ \\
\hline \multicolumn{7}{|l|}{2006} \\
\hline & $\% 50$ & 32,8 & 27,8 & 5,4 & 14,3 & 0,7 \\
\hline & $\% 60$ & 41,4 & 36,7 & 9,7 & 21,2 & 1,3 \\
\hline \multicolumn{7}{|l|}{2007} \\
\hline & $\% 50$ & 30,7 & 24,9 & 12,5 & 5,2 & 0,8 \\
\hline & $\% 60$ & 40,5 & 34,2 & 19,5 & 8,7 & 1,6 \\
\hline \multicolumn{7}{|l|}{2008} \\
\hline & $\% 50$ & 29,5 & 24,2 & 13,3 & 5,2 & 0,7 \\
\hline & $\% 60$ & 40,2 & 33,6 & 20,8 & 8,5 & 1,3 \\
\hline \multicolumn{7}{|l|}{2009} \\
\hline & $\% 50$ & 32,7 & 27,2 & 13,9 & 5,1 & 1,2 \\
\hline & $\% 60$ & 41,8 & 36,7 & 21,5 & 8,5 & 1,8 \\
\hline \multicolumn{7}{|l|}{2010} \\
\hline & $\% 50$ & 28,8 & 27,5 & 14,3 & 4,5 & 1,0 \\
\hline & $\% 60$ & 39,3 & 37,3 & 20,9 & 7,8 & 1,8 \\
\hline \multicolumn{7}{|l|}{2011} \\
\hline & $\% 50$ & 28,9 & 27,0 & 13,1 & 5,8 & 1,1 \\
\hline & $\% 60$ & 38,4 & 35,8 & 20,0 & 8,9 & 2,0 \\
\hline \multicolumn{7}{|l|}{2012} \\
\hline & $\% 50$ & 30,1 & 26,1 & 13,5 & 5,9 & 1,1 \\
\hline & $\% 60$ & 39,1 & 33,8 & 20,0 & 9,3 & 1,9 \\
\hline \multicolumn{7}{|l|}{2013} \\
\hline & $\% 50$ & 26,6 & 23,7 & 12,4 & 5,6 & 1,8 \\
\hline & $\% 60$ & 37,5 & 33,5 & 20,0 & 9,1 & 2,7 \\
\hline \multicolumn{7}{|l|}{2014} \\
\hline & $\% 50$ & 27,7 & 25,1 & 12,5 & 5,7 & 1,3 \\
\hline & $\% 60$ & 38,1 & 34,2 & 19,6 & 9,3 & 2,2 \\
\hline
\end{tabular}

Tablo 2' de 2006 yllından 2014 yllına kadar gelirlerine ve eğitim seviyelerine göre yoksulluk oranları verilmektedir. 2006 yılından 2014 yılına kadar en büyük yoksulluk oranı okuma yazma bilmeyen kişilerde gerçekleşmektedir. Yine en düşük yoksulluk oranı Türkiye’de yükseköğrenim mezunlarında görülmektedir. 2006 yılı dışında tüm yıllarda eğitim seviyesi arttıkça, yoksulluk oranı azalmaktadır. 
Tablo 3. Eğitim ve cinsiyete göre yoksulluk oranı (\%) (www.tuik.gov.tr 08.02.2015)

\begin{tabular}{|c|c|c|c|c|c|c|c|c|c|c|c|c|}
\hline \multirow{2}{*}{$\begin{array}{l}\text { Eğitim } \\
\text { durumu }\end{array}$} & \multicolumn{3}{|c|}{2006} & \multicolumn{3}{|c|}{2007} & \multicolumn{3}{|c|}{2008} & \multicolumn{3}{|c|}{2009} \\
\hline & $\begin{array}{l}\text { Top- } \\
\text { lam }\end{array}$ & Erkek & Kadın & $\begin{array}{l}\text { Top- } \\
\text { lam }\end{array}$ & Erkek & Kadın & $\begin{array}{l}\text { Top- } \\
\text { lam }\end{array}$ & Erkek & Kadın & $\begin{array}{l}\text { Top- } \\
\text { lam }\end{array}$ & Erkek & Kadın \\
\hline TÜRKIYYE & 17,81 & 17,32 & 18,27 & 17,79 & 17,33 & 18,26 & 17,11 & 16,70 & 17,52 & 18,08 & 17,10 & 19,03 \\
\hline $\begin{array}{l}6 \text { Yaşından } \\
\text { Küçük } \\
\text { Fertler }\end{array}$ & 24,78 & 25,12 & 24,43 & 24,52 & 24,91 & 24,10 & 22,53 & 22,86 & 22,18 & 24,04 & 22,87 & 25,27 \\
\hline $\begin{array}{l}\text { Okur-Yazar } \\
\text { Değil veya } \\
\text { Bir Okul } \\
\text { Bitirmeyen }\end{array}$ & 28,10 & 27,73 & 28,34 & 28,98 & 29,13 & 28,88 & 30,50 & 30,77 & 30,31 & 29,84 & 30,34 & 29,52 \\
\hline İlkokul & 14,19 & 16,52 & 12,05 & 14,24 & 15,87 & 12,68 & 13,44 & 15,91 & 11,22 & 15,34 & 16,86 & 13,83 \\
\hline İlköğretim & 18,06 & 16,47 & 19,66 & 19,19 & 19,79 & 18,55 & 17,20 & 18,67 & 15,66 & 17,77 & 17,19 & 18,39 \\
\hline $\begin{array}{l}\text { Ortaokul ve } \\
\text { Orta Dengi } \\
\text { Meslek- }\end{array}$ & 8,07 & 9,69 & 4,89 & 9,16 & 11,06 & 5,57 & 8,34 & 9,85 & 5,78 & 9,76 & 10,89 & 7,82 \\
\hline $\begin{array}{l}\text { Lise ve Lise } \\
\text { Dengi Meslek }\end{array}$ & 5,20 & 6,06 & 4,05 & 5,88 & 7,05 & 4,09 & 5,64 & 6,00 & 5,11 & 5,34 & 5,71 & 4,76 \\
\hline $\begin{array}{l}\text { Yüksekokul, } \\
\text { Fakülte } \\
\text { ve Üstü }\end{array}$ & 1,01 & 1,28 & 0,56 & 0,81 & 0,97 & 0,53 & 0,71 & 0,88 & 0,43 & 0,71 & 0,92 & 0,40 \\
\hline
\end{tabular}

Tablo 3'te Türkiye'de 2006-2009 yılları arasında eğitim durumu ve cinsiyete göre yoksulluk oranı görülmektedir. Tüm yıllarda hem kadınlarda hem erkeklerde cinsiyet fark etmeksizin en büyük yoksulluk oranı okuma yazma bilmeyen veya bir okul bitirmeyen kişilerde görülmektedir. Ancak tüm eğitim seviyelerinde yoksulluk oranı 2006 yılından 2009 yılına gelindiğinde yoksulluk oranının azalması beklenirken, eğitim seviyelerine bağlı değerlendirmede yoksulluk oranı her seviyede azalmamaktadır. Şöyle ki 2006 yılı ile 2009 yılı toplamda mukayese edildiğinde sadece ilköğretim ve yüksekokul, fakülte ve üstü mezunların yoksulluk oranı azalmıştır. 
Tablo 4. Cinsiyet ve Eğitim durumuna göre aylık ortalama brüt ücret ve yıllık ortalama brüt kazanç (Kaynak: TÜİK, Kazanç Yapısı Araştırması)

\begin{tabular}{|c|c|c|c|c|c|}
\hline \multirow{2}{*}{\multicolumn{2}{|c|}{$\begin{array}{l}\text { Eğitim durumu } \\
\text { (ISCED, 1997) }\end{array}$}} & \multicolumn{2}{|c|}{$\begin{array}{l}\text { Aylik ortalama } \\
\text { brüt ücret (TL) }\end{array}$} & \multicolumn{2}{|c|}{$\begin{array}{c}\text { Y1lık ortalama brüt } \\
\text { kazanç (TL) }\end{array}$} \\
\hline & & \multirow{2}{*}{$\begin{array}{l}2006 \\
1107\end{array}$} & \multirow{2}{*}{$\begin{array}{l}2010 \\
1510\end{array}$} & \multirow{2}{*}{$\begin{array}{c}2006 \\
14316\end{array}$} & \multirow{2}{*}{$\begin{array}{r}2010 \\
19683\end{array}$} \\
\hline Erkek & & & & & \\
\hline & İlkokul ve altı & 784 & 1066 & 9952 & 13526 \\
\hline & $\begin{array}{l}\text { İlköğretim } \\
\text { ve ortaokul }\end{array}$ & 788 & 1061 & 9999 & 13505 \\
\hline & Lise & 943 & 1317 & 12042 & 16907 \\
\hline & Meslek lisesi & 1298 & 1649 & 17312 & 22195 \\
\hline & $\begin{array}{l}\text { Yüksekokul } \\
\text { ve üstï }\end{array}$ & 2231 & 2842 & 29258 & 37878 \\
\hline \multicolumn{2}{|l|}{ Kadın } & 1091 & 1519 & 14036 & 19728 \\
\hline & İlkokul ve altı & 650 & 874 & 8159 & 11065 \\
\hline & $\begin{array}{l}\text { İlköğretim } \\
\text { ve ortaokul }\end{array}$ & 640 & 870 & 8064 & 10949 \\
\hline & Lise & 870 & 1177 & 11182 & 15049 \\
\hline & Meslek lisesi & 944 & 1336 & 11990 & 17109 \\
\hline & $\begin{array}{l}\text { Yüksekokul } \\
\text { ve üstï }\end{array}$ & 1837 & 2380 & 23899 & 31437 \\
\hline
\end{tabular}

(1) Aylık ücret: İşveren tarafından ücretli çalışanlara referans ayında yapılan; temel ücret ödemeleri, fazla çalışma ödemeleri, vardiyalı çalışma/gece çalışması için yapılan ödemeler ve ücret niteliğindeki diğer düzenli ödemelerin toplamıdır.

(2) Yıllık kazanç: İşveren tarafından ücretli çalışana referans yılında yapılan temel ücret ödemeleri, düzenli ödemeler, düzensiz ödemeler ve aynî yardım ödemelerinin toplamidir.

Tablo 4'de Cinsiyet ve eğitim durumuna göre 2006 ve 2010 yıllarını içeren aylık ve yıllık ortalama kazanç miktarı TL cinsinden gösterilmektedir. 2006 ve 2010 yılı için yıllık ortalama brüt kazanç tüm eğitim seviyelerinde kadınların kazançları erkeklerden azdır. Yüksekokul ve üstü mezunu erkekler 2010 yılı için ortalama 37.878 TL kazanırken, kadınlar 31.437 TL kazanmaktadır. Yine meslek lisesi mezunu kadınlar 2006 yılında yıllık ortalama 11.990 TL kazanırken, aynı yıl ve eğitim seviyesinde erkekler ortalama yıllık 17.312 TL kazanmaktadır. 
Tablo 5. Cinsiyet ve Eğitim durumuna göre aylık ortalama brüt ücret ve yıllık ortalama brüt kazanç (Kaynak: TÜİK, Kazanç Yapısı Araştırması)

\begin{tabular}{|c|c|c|c|c|c|}
\hline & \multicolumn{3}{|c|}{ Ylllkk ortalama brüt ücret (TL) } & \multirow{2}{*}{$\begin{array}{l}\text { Cinsiyete } \\
\text { dayalı ücret } \\
\text { farki(1)(\%) }\end{array}$} \\
\hline & & Toplam & Erkek & Kadın & \\
\hline \multicolumn{6}{|c|}{ Eğitim durumu } \\
\hline & İlkokul ve altı & 12237 & 12597 & 10519 & 16,5 \\
\hline & İlköğretim ve ortaokul & 12192 & 12571 & 10470 & 16,7 \\
\hline & Lise & 15117 & 15531 & 13969 & 10,1 \\
\hline & Meslek lisesi & 18759 & 19442 & 15647 & 19,5 \\
\hline & Yüksekokul ve üstü & 31486 & 33574 & 28184 & 16,1 \\
\hline \multicolumn{6}{|c|}{ Meslek ana grubu } \\
\hline \multirow[t]{9}{*}{ 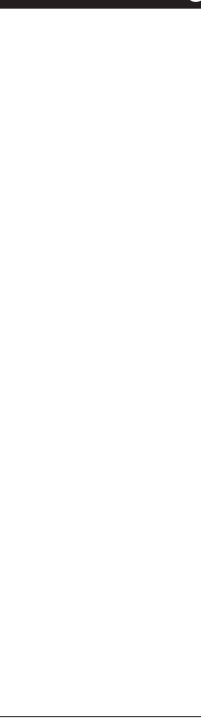 } & Yöneticiler & 43825 & 43073 & 46201 & $-7,3$ \\
\hline & Profesyonel meslek mensupları & 31520 & 34549 & 27861 & 19,4 \\
\hline & $\begin{array}{l}\text { Teknisyenler, teknikerler } \\
\text { ve yardımcı profesyonel } \\
\text { meslek mensupları }\end{array}$ & 22082 & 22536 & 20865 & 7,4 \\
\hline & $\begin{array}{l}\text { Büro hizmetlerinde ça- } \\
\text { lışan elemanlar }\end{array}$ & 18875 & 19383 & 18203 & 6,1 \\
\hline & Hizmet ve satış elemanları & 12922 & 13167 & 12188 & 7,4 \\
\hline & $\begin{array}{l}\text { Nitelikli tarım, ormancılık } \\
\text { ve su ürünleri çalışanları }\end{array}$ & 14091 & $\left({ }^{*}\right)$ & (0) & $\left({ }^{\star}\right)$ \\
\hline & $\begin{array}{l}\text { Sanatkarlar ve ilgili iş- } \\
\text { lerde çalışanlar }\end{array}$ & 15278 & 15586 & 13004 & 16,6 \\
\hline & $\begin{array}{l}\text { Tesis ve makine opera- } \\
\text { törleri ve montajcllar }\end{array}$ & 13336 & 13851 & 10518 & 24,1 \\
\hline & Nitelik gerektirmeyen meslekler & 12075 & 12449 & 10713 & 13,9 \\
\hline \multicolumn{6}{|c|}{$\begin{array}{l}\text { (1) } 2010 \text { yılı toplam ücreti esas alınarak [(erkek ücreti-kadın ücreti)/erkek ücreti } \\
{ }^{\star} \text { 100] olarak hesaplanmıştır. }\end{array}$} \\
\hline
\end{tabular}

Tablo 5’te eğitim durumu ve meslek ana grubuna göre cinsiyete dayalı ücret farkı görülmektedir. 2010 yılı verilerine dayanarak kadın ve erkek ortalama kazancı eğitim durumuna göre değerlendirildiğinde tüm eğitim seviyelerinde kadınların yıllık ortalama kazancı erkeklerden düşüktür. Cinsiyete bağlı ücret farkı en fazla meslek lisesi mezunlarında görülürken, en az lise mezunlarında görülmektedir. Meslek ana gruplarına göre cinsiyete bağlı ücret farkı değerlendirildiğinde yöneticiler hariç hemen her meslek grubunda cinsiyete bağlı ücret farkı görülmektedir. 


\section{Yoksulluğun Kadınlaşması}

Fiziksel olarak kadın olmanın dışında, toplumsal cinsiyet anlamında kadın olmanın tüm toplumlarda benzerlikler ve farklılıklar içeren çok boyutlu sorunları bulunmaktadır (Koray, 2012, s.368). Yoksulluk içerisinde kadınların ve çocukların en başta yer alan kesim olması kadın ve yoksulluk çalışmalarının 1970 yılından sonra özellikle artmasına neden olmuştur. Yoksulluğun kadınlaşması ise özelikle yoksulluk içinde kad1nın çok yer almasına istinaden 1978 yılında ilk olarak Pierce tarafından kullanılmıştır. Kadınlar yaşanan ekonomik krizler, işsizlik, düşük büyüme oranı gibi nedenlerle birlikte boşanma, eşin ölmesi ile tek başına kalması gibi nedenlerle de yoksullaşabilmektedir (Duyan, 2003, s. 360). Bugün gelinen noktada yoksulluğun kadınlaşması kavramı artık sadece yalnız yaşayan veya hane reisinin kadın olduğu aileler için değil, evli olan yoksul kadınların da yoksulluklarını ifade etmektedir (Chant, 2007, s. 30). Özellikle 1995 yılında Pekin 4. Dünya konferansında yoksulluğun kadınlaşması kavramı şu olguları ifade etmek için kullanılmıştır:

- Kadınların, yoksullukla karşılaşma olasılıkları erkeklerden daha fazladır.

- Kadınların yoksullukları erkeklerden daha büyük ve ciddi düzeydedir.

- Kadınların yoksulluk durumu gün geçtikçe erkeklere oranla artmaktadır (Ecevit, 2003, s. 85).

Yoksulluk çok çeşitli ve boyutlu görünmesine rağmen kadın yoksulluğunun bir takım ortak karakteristik özellikleri bulunmaktadır. Bunlar:

- Kadınlar erkeklere oranla yoksulluğu daha yüksek oranda yaşamaktadır.

- Kadınların yoksulluk içindeki yüksek oranı nedeniyle kadınlar yoksulluğu erkeklerden daha şiddetli ve derinden yaşamaktadır.

- Kadınlar erkeklere oranla daha kalıcı yoksulluk yaşamaktadır.

- Kadınların yoksulluğu orantısız biçimde yüklerini de arttırmaktadır.

- Kadınlar yoksulluğu ortadan kaldırmak için erkeklere oranla daha fazla bariyerle karşılaşmaktadır.

- Yoksulluğun kadınlaşması ile hane halkının kadınlaşması arasında bir bağ vardir.

- Yoksulluk içindeki en yoksul hane halkı ise hane reisinin kadın olduğu ailelerdir.

- Hane reisinin kadın olduğu yoksulluk diğer kuşaklara da aktarılmaktadır (Chant, 2008, s. 167). 
Genel olarak kadın yoksulluğunun 2 temel sorunu bulunmaktadır. Eğitim olanaklarına erişememe sorunu ve kadınların işgücü piyasasındaki konumudur. Yoksulluğun kadınlaşması ile ilgili yapılan çalışmalarda kadın eğitiminin ve istihdamının arttırılmasının yoksulluğun kadınlaşmasını azaltacağı vurgulanmaktadır. Ancak görünen o ki sadece istihdamın artması kadınların istihdama katıldığı alandaki işler nedeni ile yoksulluğu azaltmamaktadır. Kadınların işgücü piyasasındaki konumu kadın yoksulluğunun çarpıcı yönüdür. Kadınlar genellikle verimlilik ve ücret düzeyi düşük, hizmet sektöründe fazla beceri gerektirmeyen, güvencesiz işlerde istihdam edilmektedir ( Öztürk ve Çetin, 2009, s. 2677). İşgücü piyasalarının yapısı gereği kadınlar kayıt dışı sektörlere yönelmek zorunda kalmakta, bu durum kadın yoksulluğunu arttırmakta yoksulluk arttıkça da kadınlar güvencesiz işlere razı olmak zorunda kalmaktadır (Şener, 2009, s. 2).

\section{Kaynakça}

Altan, Ö. Z. (2004). Sosyal Politika Dersleri. Eskişehir: Anadolu Üniversitesi Yayınları, No: 1592.

Buz, S. (2003). Yoksulluk ve Göç. Yoksulluk Sempozyumu. İstanbul: Deniz Feneri Yayınları.

Buğra, A. ( Aralık 2005). Yoksulluk ve Sosyal Haklar. Sivil Toplum Geliştirme Merkezi Derneği için Hazırlanan Danışman Raporu.

Chant, S. (2007). Gender, Generation and Poverty. UK: Edward Elgar Publishing.

Chant, S.(2008). The 'Feminisation of Poverty' and the 'Feminisation' of Anti-Poverty Programmes: Room for Revision?. The Journal of Development Studies (44/2).

Doğan, E. (2004). Türkiye’de Yoksulluğun Ölçülmesi. Ankara: Kalkınma Bakanlığı, Yayın No:2880.

Duyan, Ç. G. (2003). Türkiye’de Kadın Yoksulluğu: Halk Ekmek Büfelerinde Bir Araştırma. İstanbul: Deniz Feneri Yayınları

Ecevit, Y. (2003). Toplumsal Cinsiyetle Yoksulluk İlişkisi Nasıl Kurulabilir? Bu İlişsi Nasıl Çalışabilir?.C.Ü Tip Fakültesi Dergisi (Özel Eki, 25/4).

Eren, A., Bahar, O. (2004). Yoksulluğu Kavramsal Bir Bakış: Dünya ve Türkiye’deki Görünümü. İktisat İsletme ve Finans (19/220).

Gündoğan, N. (2008). Türkiye'de Yoksulluk ve Yoksullukla Mücadele. Ankara Sanayi Odası, 2008, 8 Şubat, 2016 tarihinde ulaşılmıştır, (http://www.aso.org.tr/kurumsal/media/ kaynak/TUR/asomedya/ocak-subat2008/Dosya.pdf)

İncedal, S. (2013). Türkiye’de Yoksulluğun Boyutları: Mücadele Politikaları ve Müdahele Araçları. Uzmanlık Tezi, Ankara: Aile ve Sosyal Politikalar Bakanlığı.

Koray, M. (2012). Sosyal Politika. Ankara: İmge Yayınevi.

Sam, N. (2008). Yoksulluğa Bir Bakış Biçimi: Kapasite Yaklaşımı. Uludağ Üniversitesi İİBF Dergisi (27/1).

Sen, A. (2004). Özgürlükle Kalkınma (çev. Yavuz Alagon) İstanbul: Ayrıntı Yayınları.

Şener, Ü. (2009). Kadın Yoksulluğu Değerlendirme Notu, TEPAV (1/11).

Şenses, F. (2002). Küreselleşmenin Öteki Yüzü Yoksulluk. İstanbul: İletişim Yayınları. 
Tokol, A., Alper, Y. (2015). Sosyal Politika. Bursa: Dora Yayıncılık.

Topgül, S. (2013). Türkiye'de Yoksulluk ve Yoksulluğun Kadınlaşması. Cumhuriyet Üniversitesi İIBF Dergisi (14/1).

Öztürk, M., Çetin, I. B. (2009). Dünyada ve Türkiyede Yoksulluk ve Kadınlar. Journal Of Yaşar University (3/11).

Uzun, A. M. (2003). Yoksulluk Olgusu ve Dünya Bankası. C.Ü. İktisadi ve İdari Bilimler Dergisi (4/2).

Yusufoğlu, Ö. Ş. (2010). Kadın Yoksulluğu Üzerine Sosyolojik Bir Araştırma: Elazığ Örneği. Yüksek Lisans Tezi, Fırat Üniversitesi Sosyal Bilimler Enstitüsü Sosyoloji Ana Bilim Dalı.

“İnsani Gelişme Raporu,” UNDP, 8 Şubat, 2016 tarihinde ulaşılmıştır,http://issuu.com/undpturkiye $/$ docs $/$ name1d $7344 ? \mathrm{e}=4172436 / 2847987 \mathrm{~S}$ 


\section{İslam Hukukunda Toplumsal Cinsiyet Söylemi: Eşitlik mi?-Adalet mi?}

\section{Gender Discourse in İslamic Law: Equality or Justice?}

Büşra Bilgin ${ }^{1}$

İslam Hukukunda Kadın, Aile ve Toplumsal Cinsiyet, Judith E. Tucker, çev. Zeynep Esra Koca, İstanbul: Aç1lım Kitap, 2015, 336 s.

İslam Hukukunda Kadın, Aile ve Toplumsal Cinsiyet isimli kitap, yazarın Osmanlı dönemi mahkeme kayıtlarına dayanarak -farklı hukuk ekollerinin görüşlerini de değerlendirmeye almak suretiyle- İslam Hukuku uygulamalarında kadının konumunu ve İslam toplumunda kadına yüklenen cinsiyet rollerini tartışmaktadır. Yazar çalışmasında modernleşme sürecinde İslam coğrafyasında yaşanan siyasî ve hukukî değişimler ekseninde fikhın savrulduğu konumu ve kadının toplumdaki konumunun tartışmaya açıldığı dönemlere de getirerek Müslüman kadının toplumsal cinsiyet rolü açısından yaşadığı ve halen süregelen değişimi ele almaktadır.

Kitabın Türkçe’ye kazandırıldığı bu basımın başında ayrıca Nazife Şişman’n Türkiye özelinde günümüz Müslüman toplumlarında toplumsal cinsiyet temelli tartışmalara ve feminist hareketlere yönelik değerlendirmelerini bizzat kendi tecrübeleri üzerinden ifadelendirdiği bir takdim yazısı bulunmaktadır. Şişman’ın bu açıdan yeni ve ufuk açıcı okumalara yönlendiren bu yazısı eseri okurken kılavuz olabileceği gibi tek baş1na da dikkat çekici bir metin olarak karşımıza çıkmaktadır. Özellikle İslam ve kadın meselesinin İslam medeniyetini yargılama aracı olarak konumlandırılmasını eleştirerek sorguya çekilen tarafın itiraf yahut savunma diline mecbur bırakıldığını anlattığ bölümde, toplumsal cinsiyet çalışmalarında niçin iki ayrı uca savrulduğumuzu kısa fakat çarpıcı biçimde ortaya koymaktadır. Yine bu minvalde Müslüman toplumlardaki toplumsal cinsiyet araştırmalarında soruyu soran ve sorunun muhatabı arasındaki hiyerarşik ilişkiye dikkat çekmiş; soru soranın seküler, sorunun muhatabının ise "her şeye rağmen ısrarla Müslüman olmaya devam eden -ezilmiş- kadın” şeklinde formüle etmiştir. Fakat Tucker'ın çalışmasının bu hiyerarşik yaklaşımdan azâde olarak meseleyi İslam hukuku ve tarihî perspektif ekseninde ele aldığını belirtmiştir.

Tucker, kitabına çalışmasını hazırladığı dönemde Müslüman toplumlardan haber aldığı kadın hakkı ihlallerini tavsif ederek başlamış ve çizdiği olumsuz tabloya rağmen oluşan paradoksu şöyle sunmuştur: “...bu durumda birçok Müslüman kadın ve on-

1 Marmara Üniversitesi İlahiyat Fakültesi Din Sosyolojisi Bölümü Doktora Öğrencisi, busrakucukkayis@gmail.com 
ların müttefiki olan erkekler neden İslamî ilkelerin bu dünyada ve ahirette iyilik ve adaletin kaynağı olduğuna; İslami uygulamaların -muhtemelen bir kısmının gözden geçirme ve revizyon gereksinimi olsa da- kadın hakları, ayrıcalıkları ve adaleti için en iyi garanti olduğuna sıkı sıkıya inanıyor?” Kitap boyunca esasında bu paradoksu anlamaya çalışırken gelişen bir metni takip etmekteyiz. Zira bu cümle her ne kadar yazarın taaccübünü aktardığı izlenimini verse de onun İslam hukukunun esnek ve toplumsal ihtiyaçlara göre şekillenebilir bir özü olduğuna dair inancını da bünyesinde barındırmaktadır.

Yazar, kitabı dört temel meseleyi yine dört tema üzerinden inceleyerek kurgulamıştır. Kendi ifadesiyle temsiliyet, ayrımcılık, erkek bakış açısıyla norm oluşturma ve hukukun cinsiyetçileștirilmesi meselelerini evlilik, boşanma, hukuki şahsiyet olmalı (veli, şahit ve mülk sahibi olmak bakımından), mekân ve cinsellik temaları ekseninde ele almıştır. Bu temalar aynı zamanda kitabın bölümlerine de karşılık gelmektedir.

İslam hukuku, kadın ve toplumsal cinsiyet kavramlarını ilk bölümde giriş nev'inde tartışan yazar "Zevce Olarak Kadın ve Zevc Olarak Erkek: Evlilik Mutabakatının Oluşumu" başlıklı ikinci bölümde; evliliğin İslam hukuk geleneği içindeki usulü, uygulanışı ve kadın-erkek arasındaki rol paylaşımını değerlendirmiş, daha sonra reform süreci sonrası modern dönemde revize edilen uygulamalara yer vermiştir. Günümüzde İslam toplumlarında bu minvaldeki tartışmalara ve kadınların taleplerine de kısaca değinerek bölümü sonlandırmıştır. Özellikle evlilikteki hak ve yükümlülükler bahsinde yazarın salt eşitlikçi yaklaşımının onu kapsayıcılıktan uzak bir noktaya taşıdığını söylemek mümkündür. Kadına evlilikte nafaka, çocuğun bakımı için ücret ödenmesini kadınların aile içi sorumluluklarına atfedilen saygıyla bağdaştırdığı halde erkeğin ağır yükünün aslında bağımsız ataerkil imtiyaz imajını desteklediğini söyleyerek çelişkili bir ifade sunmaktadır.

Tucker, "Boşanmada Hakların Tayini” başlıklı ikinci bölümde yine aynı şemadan hareketle boşanmayı; İslam hukuk geleneğindeki tasviri, İslam’ın boşanmaya bakış açısı, reform süreci ve güncel gelişmeler bağlamında ele almıştır. Yazarın boşanmaya dair görüşleri çok daha keskin bir ayrılık üzerinden şekillenmektedir. O’na göre İslam, kadın ve erkeği talak konusunda tamamen ayrımcı bir düzleme oturtmuştur. Erkeğe mahkeme makamına gitmeksizin isteğine göre talak hakkını kullanma imkanı vermesine rağmen kadının boşanma için ancak fesih yetkisiyle mahkemeye başvurabilir vaziyette olması boşanmanın "sevilmeyen bir mübâh olması" hasebiyle engellenmek istenmesi fakat bu minvalde fikhi manada tek taraflı bir kısitlamaya gidilmesinin ancak erkeğin imtiyazlarını korumak kaygısıyla gerçekleşmiş bir vakı olduğunu söylemektedir. Yine Tucker’a göre boşanma sonrasında kadına geçici nafaka bağlanması, akabinde babası yahut kardeşinin bakmak zorunda olması, kadını zayıf ve korunmaya muhtaç biçimde tasvir edip bağımlı bir şahsiyet olmaya zorlamaktadır. Yazarın bu bölümdeki ifadelerinde kadın ve erkek boşanma yükümlülüklerini değerlendirirken günümüz toplumsal rolleri üzerinden yol aldığını hissetmek mümkündür. Fakat günümüzde nafaka ve maldan pay almasının kadının da iş gücüne dahil olduğu aileler 
açısından çözülmesi gereken bir mesele olduğunu dikkat çekici bulmuştur.

"Hukuki Özneler Olarak Kadın ve Erkek: Ev İdaresi ve Şahitlik" başlıklı dördüncü bölümde Tucker; kadın ve erkeğin mülk edinme, mülkü idare etme, evin geçimini sağlama, mirastan pay alma ve hukuki özne olabilme (şahitlik) hususları üzerinden rollerini inceleyip tartışmıştır. Yine hem tarihi süreci ve işleyişi ele almış hem de modern dönemdeki uygulamaları değerlendirerek güncel duruma da değinmiştir. Mülk edinme ve ticaret yapma ehliyeti bakımından bağımsız bir şahsiyet olarak tanımlanan kadının evlilik mevzusunda bağımlı hale getirilmesini eleştiren yazar bu durumun toplumsal taleplerin şekillendirdiği bir olgu olduğunu iddia etmektedir. “...aksi yöndeki tüm baskılara rağmen kadının mülkiyet konusunda temel eşitliğiyle ilgili mefhumların bu kadar sıkı sıkıya korunmuş olmasını bile dikkate değer buluyorum." cümlesi ile kadınların mülk edinip işletebilme hakkını toplumsal baskıdan ve hukukun hüküm koyucularının elinden kurtulabilmiş yahut gözden kaçıvermiş bir eşitlikçi unsur olarak tarif etmesi mantık sınırlarını zorlayan bir yorum izlenimi uyandırmaktadir.

“Toplumsal Cinsiyet Mekânında Kadın ve Erkek: Teslimiyet” başlıklı beşinci ve son bölümde yazar cinsellik karşısında kadın ve erkeğe konan sınırları bu bağlamda evlilik dışı ilişkinin cezasını ve tesettür meselesini irdelemiştir. Tucker'a göre kadın ve erkek cinselliğinin kontrol altına alınması Müslüman toplumun düzeni için önem arz etmekteydi. Ancak bu kontrolün kadın bedenine yönelik daha fazla yaptırım getirdiğini öne süren yazar tesettürün günümüz modern toplumlarındaki yargılanış biçimine ise hiç değinmemiştir. Müslüman kadının daha fazla fedakarlık yapmaya zorlanması şeklinde ifade ettiği tesettürün hukuk literatüründe keskin çizgiler ve ölçütlerle belirlenmediği, zamana ve bölgeye göre nispeten muhayyer bırakıldığını vurgulamıştır. Konunun güncel yönünü anlatırken Batılı hakim anlayışın Müslüman kadını kurtarılması gereken bir obje ${ }^{2}$, tesettürü ise Müslüman kadının infaz edilmekte olan cezası şeklinde konumlandırması meselesine neredeyse hiç değinmeyen Tucker, Müslüman kadınların batılı paradigmaya yönelik eleştirilerini ancak İslamî inisiyatifleri de eleştirdikleri takdirde işitmeye değer bulmuştur demek mümkündür.

Yazarın Osmanlı hukuk tarihi kapsamında da ele alınabilecek araştırmalarını dönemin toplumsal cinsiyet ve kadın ilişkisi bağlamında değerlendirmesi elbette bu alanda hatırı sayılır miktarda verinin işlenmesini sağlamıştır. Bu sayede toplumsal tarihi anlamlandırmakla kalmayıp günümüz Türkiye’sinde ve hatta Osmanlı coğrafyasındaki Müslüman toplumlarda toplumsal cinsiyet paradigmasının kökenini kavrama imkanı bulmaktayız. Tucker'ın çalışmasının bu zaviyeden kıymetini göz ardı etmeksizin bazı ön kabulleri sebebiyle İslam hukukunda toplumsal cinsiyet meselesi dahilinde okuyucuya kapalı kalması muhtemel hususların yahut belli sonuçlara kasten yönlendiren ifadelerin varlığını da belirtmek gerekir. Zira Tucker çalışmasının temelinde Osmanlı mahkeme kayıtlarından ve İslam hukuku alimlerinin fetvaları üzerinden meseleyi ele alırken; İslam hukukunun dönemine göre ilerici olan unsurlarına vurgu yaparak bu

2 Ayrıntılı bilgi için bkz. Lila Abu-Lughod, Do Muslim Women Need Saving?, Harvard University Press, 2013 
durumu İslam hukukunun esnek ve revizyona imkan veren yapısından kaynaklandığını belirtmektedir. Dolayısıyla günümüzde bu alanda yaşanan nizâlarda yine bu esnek yapı mucibince cinsiyet eşitliğine dayalı reformlara gidilmesi gerektiğini salık vermektedir. Öte yandan yazarın cinsiyet eşitliği eksenindeki bakış açısına göre uygun bulmadığı uygulamaları; toplumun İslam hukukuna yaptığı tesir yahut ataerkil sistemde erkeğin imtiyazının korunması çabası olarak ele alıp eşitlik seviyesine dönüştürülmesi gereken "yanlış uygulamalar" șeklinde nitelemesi bütüncül bir değerlendirme imkanını ortadan kaldırmaktadır. İslam hukukunu; kaynaklarını ve uygulamalarını birbirini tamamlayan parçaların oluşturduğu bir sistem olarak ele almak yerine bugünün toplumsal cinsiyet ve eşitlik idealinden hareketle parçalardaki fazlalık ve eksiklikleri tartışmakta ancak bu parçaların tamamlayıcı bir bütünü oluşturma ihtimalini yok saymaktadır. İslam hukuku uygulamaları kaynaklarından biri olması itibariyle örften ve toplumsal kabullerden etkilenmiş olabilir lakin tüm hukuk sistemini toplumsal işleyiş sonucu ortaya çıkan tarafsızlıktan yoksun ve kadını özellikle bağımlı ve yardıma muhtaç kılmayı amaçlayan bir doktrin şeklinde tarif etmek şüphesiz haksız bir yakıştırma olacaktır. İslam’ın ve ona bağlı olarak gelişen hukuk doktrini yapısının -mezhep farklılıkları ve alimlerin görüş ayrılıklarına rağmen- insanlar arasında adaleti tesis etmeyi gaye edindiğini hatırlamak gerekmektedir. Kadın-erkek cinsiyet rollerini değerlendirmede İslam hukuku ele alındığında aile ve toplum bağlamında görevlerin adalet üzere pay edilmesi için çaba gösterilmiştir. Tucker'ın bu çalışması; İslam hukukunun cinsiyetler arasında tesis etmeyi hedeflediği adalet prensibini ele almaksızın eşitlik üzerine yaptığı kesin vurgular çalışmanın objektifliğini tartışmaya açı hale getirse de toplumsal cinsiyet rollerinin dağılımını anlamada ve İslam hukuku üzerinde adalet eksenli bir okumanın mümkün olup olmadığını test edebilmek adına kaynak teşkil edecektir. 


\title{
Feminist Söylem Bağlamında Kadın Özgürlüğ̈̈i
}

\section{Women's Freedom in the Context of Feminist Discourse}

Zehra Zeynep Sadıkoğlu ${ }^{1}$

\author{
Kadın Özgürlügünün Sorunları, \\ Evelyn Reed, \\ çev. Zeynep Saraçoğlu, Yazın Yayıncılık, Ekim 1985, 121 s.
}

Modern Batı düşüncesi kendini geleneğe karşı konumlayarak inşa etmiştir. Bu inşa sürecinde "öteki” konumuna düşen ve dolayısıyla gelenekle bağlantılı olan olgu merkeze yerleştirilen olguyla aynılaşması kaydıyla ve aynılıkları ölçüsünde değerli kabul edilmiştir. "Erkek" karşısında öteki konumuna düşen "kadın" için de aynı şey söz konusudur. Bu çerçevede kadın farklılıkları yok sayılıp erkekle aynılaştığı sürece makbul sayılmıştır. Bir başka ifade ile kadın erkekle "eşit” olduğu takdirde değerli kabul edilmiştir. Demokrasi, sekülerizm, rasyonalite, pozitivizm, feminizm vb. düşünsel-siyasal akımlar da geleneğin bu ötekileştirilmesi ihtiyacından yola çıkarak üretilmiş akımlardır. Bu akımlardan biri olan feminizmin savunucularından Evelyn Reed'in Kadın Özgürlüğünün Sorunları adlı kitabında ortaya koymuş olduğu iddialar da bu temel üzerinden yükselmektedir.

1905-1979 yılları arasında yaşamış olan Evelyn Reed, 1940 yılından başlayarak ikinci dalga feminizm olarak adlandırılan kadın özgürlügü hareketinde aktif rol almıştır. Esasen resim eğitimi almış olan Reed, kariyeri bu yönde olmasa da insanbilimci olarak kabul görmüş, kadın bağımsızlığı hareketini bilimsel temellere oturtmak için çalışmalar yapmıştır. Bu çalışmalardan birini teşkil eden Kadın Özgürlüğünün Sorunları farklı dergilerde yayımlanmış altı makaleden oluşmaktadır.

"Kadınlar ve Aile, Tarihsel Bir Bakış" başlıklı ilk bölümde Reed, kadın sorununun çözümüne yönelik olarak insanlık tarihinin ilk dönemlerine dönmek gerektiğini ileri sürmüş ve antropoloji biliminin insanlığın geçmişi hakkında hüküm süren yanlış anlayışları ve kadınlar hakkındaki önyargıları bertaraf etmedeki katkısını göstermeye çalışışıtır. Bu çerçevede Morgan’ın ilkel topluma yönelik çalışmalarını referans olarak göstermiştir. Ayrıca gerek Morgan’ın gerek Darwin’in çalışmalarının etkilemiş olduğu Friedrich Engels'in Ailenin, Özel Mülkiyetin ve Devletin Kökeni (1884) adlı kitabında ortaya koyduğu toplumsal kökenin emek kuramına kadın sorununun çözü-

1 İstanbul Üniversitesi Sosyoloji Anabilim Dalı Doktora Öğrencisi, zeynebsadikoglu@gmail.com 
münde önemli bir anlam yüklemiştir.

Reed'e göre Engels, ilkel sınıfsız toplumla sınıflı toplumların karşılaştırmasını yaparak antropologlarca toplanan malzemeden sosyolojik sonuçlar çıkarmıştır. Buna göre Engels mülkiyet haklarının bulunmadığı, ilk avc1-yiyecek toplayıcı toplumların yeniden üretici güçlerinden dolayı kadınlar tarafından yönetilmiş olabileceğini iddia etmiştir. Anaerkil toplum ya da ilkel komünal toplum olarak adlandırdığı bu toplum biçiminin, henüz özel mülkiyetin ve devletin olmadığı, genel olarak toplumda sınıf egemenliğine dayalı ilişkilerin ve onun ürünü ya da uzantısı öteki toplumsal sömürü biçimlerinin ortaya çıkmadığı bir toplum biçimi olduğunu belirtmiştir. Yerleşik tarıma geçiş ve hayvanların evcilleştirilmesi, dolayısıyla toprağın ve malların özel mülkiyet haline gelmesiyle zenginliğin soy yoluyla aktarılması için evlâtların meşruiyetini sağlamanın erkeklerin gözünde önem kazandığını, böylelikle erkeklerin kadınların yeniden üretici gücünü kontrol etmeye başladıkları ataerkil sistemin yükseldiğini ileri sürmüştür.

Ancak "anaerkillik" kavramının literatürde iki yaygın şekilde kullanıldı̆̆ını görmek mümkündür. Birincisi, annelerin aile reisi olduğu bir toplumsal örgütlenme tipine işaret ederken ikincisi, soyun annelere göre belirlendiği yaygın kullanımla özdeştir. Anaerkilliğin daha spekülatif olan ve evrimci kuramlara dayanan ikinci kullanımı annelerin başlıca güç konumlarını ellerinde tuttukları bir topluma göndermede bulunur. Bu kullanımın dayandığı temel iddia doğanın kadını toplumu yönetecek özelliklerle donatmış olduğu, ataerkilliğin doğanın koyduğu kanuna başkaldırı niteliğinde olduğu, dolayısıyla tüm insanlığın iyiliği ve doğal durumun tesisi için kadına toplumsal önderliğin geri verilmesidir. Ancak tüm evrimci kuramlarda bulunan ve Engels tarafından da ileri sürülen tarih öncesi insanlığın, anaerkillikten ataerkilliğe geçişle karakterize edildiği iddiası, yirminci yüzyılın başında önemini yitirmiştir. Son araştırmalarda toplumsal gelişmenin tek bir çizgiyi izlediği inancı gücünü yitirmiştir. Ayrıca bu spekülasyonun feminist kuram açısından çekiciliğine rağmen, anaerkilliğin bu ikinci anlamda tarihte her hangi bir zamanda ya da bir toplumda var olduğunu gösteren arkeolojik veya antropolojik bir kanıt yoktur (Marshall, 2005, s. 22). Bu nedenle de feminist akım içerisinde kadının yönetici olarak etkin olduğu anaerkil dönem vurgusu kadının tanrıça olduğu anaerkil toplum vurgusuna doğru kaymıştır. Bu sırada da tarihsel kanıtlardan çok sıklıkla mitlere referans verilmiştir.

“Kadınların Aşağı Cins Oldukları Miti” başlıklı ikinci bölümde ise Reed, bu mite göre erkek üstünlügünün tarihin belli bir aşamasında ortaya çıkan tarihsel bir fenomen değil doğal bir yasa olduğunu belirtmekte ve bu mite karşı çıkmaktadır. Ayrıca sınıflı toplumun annelik vurgusu ile kadının "hayvansal" işlevlerini vurguladığını belirten Reed, bunu kaba maddecilik olarak eleştirmektedir. Fakat aynı zamanda anneliğin kutsallaştırılmasını da eleştirmektedir. Böylece kadının hem aşağılama hem kutsama yoluyla tutsak edildiğini iddia etmektedir.

Kitabın bu bölümünde de Engels'in Ailenin, Özel Mülkiyetin ve Devletin Kökeni çalışmasına başvuru yoluyla kadınların doğal olarak aşağı cinsten olduğu şeklindeki 
miti çürütmek için ilkel kadınların harcadıkları emeğin ayrıntılı bir dökümünü çıkar$\tan$ Reed, tarımın ve hayvanların evcilleștirilmesinin kadınların çabaları sonucunda ortaya çıkmış zaferler olduğunu belirtmektedir. Erkekleri avcılığa bağımlılıktan kurtaran koşullar ile cinsler arasında bir iş bölümünün söz konusu olmaya başladığını ve bu gelişmenin anaerkinin yıkılması ve kadınların köleleşmesini getiren koşullar olduğunu iddia eden Reed, erkeklerin egemen konuma geçmesiyle kadınların üretken yaşamdan mahrum bırakıldığını ve annelik işlevlerine itildiğini ileri sürmektedir.

Reed'in bu bölümdeki temel argümanı cinslerin birbirinden farklılıklarının tabiatlarından değil toplumların cinslere yüklediği rollerden ve algılardan kaynaklandığıdır. $\mathrm{Bu}$ sebeple kadınların aslında toplum tarafından kendilerine yasaklanan tüm rolleri üstlenebilecekleri iddia edilmektedir. Ancak Reed'in bu iddialarına karşllık bugün, toplumsal hayatın bütün alanlarında erkekle eşit durumda var olmanın kadını mutlu etmediği anlaşılmıştır. Kadın hem "kadına ait" olarak tanımlanan alanda ailesiyle vakit geçirmek, çocuğunu yetiştirmek, duygularını ve kendisini ifade edebilmek hem de sosyo-ekonomik alanda var olabilmek istemektedir. Ayrıca iki cinsin her alanda eşit olduğu iddiasının bir getirisi olarak cinsel özgürlüğün ve serbest cinsel ilişkinin sonuçlarının en çok kadını incitiyor oluşu mutlak eşitlik savının tartışılmasına sebep olan diğer bir etken olmuştur (Erdoğan, 2011, s. 6). Dolayısıyla kadının toplum içerisindeki konumunun adalet perspektifiyle ele alınması gerektiğini söylemek yanlış olmasa gerektir.

"Kadınlar Kaderlerini Denetleyebilmeyi Nasıl Kaybettiler, Bunu Yeniden Nasıl Kazanabilirler?” başlıklı üçüncü bölümde ise Reed ailenin her zaman var olmuş olduğu ve kökleri insanların cinsellik ve üreme gibi temel biyolojik ihtiyaçlarında yattığı için ilelebet var olacak doğal bir birim olduğu savının eleştirilmesi gerektiğini ve artan boşanma oranlarını delil göstererek aile kurumunun ortadan kalkmaya yüz tuttuğunu ileri sürmektedir. Bu çerçevede aile kurumunun varlıklı bir sınıf tarafından kendi mülkiyet çıkarlarına hizmet etmesi için yaratılmış olduğunu, ancak mülkiyete sahip olmayan sınıflara doğru yayılmasını ve kitlesel nitelik kazanmasını kapitalist sınıfsal sömürü tarzında aramak gerektiğini belirtmektedir.

Değerlendirmenin ilk kısmında Reed'in arkasını yasladığı antropolojik çalışmaların bugün geçerliliklerini yitirdiklerini belirtmiştik. Ayrıca belirtmek gerekir ki evlilik artık ömür boyu sürecek olan bir birliktelik olarak kabul edilmemektedir. Bugün boşanmaların olağanlaşması gibi, boşanma sonrası evlilikler de olağanlaşmıştır. Tek ebeveynli ailelerinde sayısında artış olmuştur. Ayrıca birçok çocuk bir ebeveynin üvey olduğu, ancak ayrılmış veya boşanmış doğal ebeveynle düzenli iletişimin sürdürüldüğü ailelerde büyümektedir. Ancak hane yaşamının bu diğer biçimlerine rağmen, insanların çoğu, hayatlarının büyük kısmını çoğunluk tarafından kabul gören ailelerde yaşamaktadır (Giddens, 2005, s. 126). Dolayısıyla ailenin ortadan kalkmaya yüz tutmuş ve gelecekte bir zamanda yok olacak bir kurum olduğu iddiası geçersiz görünmektedir. 
“Kadınlar Kast mı, Sınıf mı, Ezilen Cins mi?” başlıklı dördüncü bölümde Reed'in iddiasına göre kadınların ezilmesinin nedenleri tarihsel ve toplumsal niteliktedir. Buna göre anaerkil toplumdan kapitalist topluma doğru evrildikçe, kadınların iktisadî bağımsızlıkları derece derece ellerinden alındıkça toplumsal itibarlarını yitirmişlerdir. Evrimsel bir aşamayı teşkil eden kapitalist düzende kadınlar, ne kast ne de ayrı bir sınıftır; onlar çocuk yetiştirme, ev işlerini yerine getirme ve aile için tüketim maddelerinin satın alınması işlevlerine hapsedilmiş, dolayısıyla her sınıf veya kastta bir şekilde ezilmiş cinsi temsil etmektedirler.

Bu bağlamda şunu belirtmek gerekir ki Reed'in de dâhil olduğu ikinci dalga feministler devlet eliyle yürütülen kapitalizmin ekonomizmine, devletçiliğine, aynı zamanda erkek merkezciliğine ve müttefiklerinin cinsiyetçiliğine karşı çıkmışlardır. Dolayısıyla cinsiyet eşitsizlikleriyle mücadele etmek, çocuk ve ev bakımının değersizleştirilmesine ve ücretli ya da ücretsiz cinsiyetçi işbölümüne son verme, devletin elinde tuttuğu gücü demokratikleştirmek, sivillerin katılımını arttırmak, denetime daha açık kılmak ve devletle toplum arasındaki iletişim akışını arttırmak gibi haklı taleplere sahiplerdir. Ancak bu noktada kapitalizmin tarihte belirli kopuş anlarında, kendisine yöneltilen eleştiri noktalarını telafi etmek suretiyle, kendisini yeniden yarattığını akılda tutmak gerekmektedir. Böyle zamanlarda, kapitalizmin ortaya çıkan yeni formunu meşrulaştırmak için kapitalizm karşıtı eleştiri unsurlarının yeniden anlamlandırılması yoluyla özünde anlamsız bir bitip tükenmek bilmeyen sermaye birikimini sırtlanmaları için yeni nesilleri motive edecek gerekli ahlâkî boyutun kazandırılması mümkün olmaktadır. Bu çerçevede günlük yaşam mücadelelerine ahlâkî bir anlam yükleyen ikinci dalga feministler, toplumsal yelpazenin her iki tarafındaki kadınları da cezbetmiştir. Dolayısıyla kadınların özgürlük hayali kapitalist sermayeye itici bir güç niteliği kazanmıştır (Fraser, 2009, s. 97-117). Sonuç olarak Reed'in de dâhil olduğu ikinci dalga feminizmin yeni neoliberalizm ruhunun ana bir unsurunu hazırlamış olduğunu söylemek mümkündür.

“Kozmetikler, Moda ve Kadınların Sömürülmesi” başlıklı beşinci bölümde Reed, kozmetik ve modanın tarihsel gelişimini vererek kadının kozmetik ve modanın konusu haline gelmesinin kapitalist toplumla birlikte ortaya çıktığını belirtmektedir. Ancak burada kullanmış olduğu argümanlar bilimsel nitelikten yoksun, kendi savını desteklemeye yönelik varsayımlar niteliğindedir. Bunlara örnek vermek gerekirse; ilkel toplumda kozmetiğin sadece insanları işaretlemek amacıyla kullanıldığı, sınıflı toplumda kozmetik ve modanın aristokrasinin bir ayrıcalığı olarak ortaya çıktığı, bir sınıf ayrımı niteliği taşıdığı, burjuva adetleri feodal uygulamaların yerine geçince belli tarihsel nedenlerden ötürü erkeklerin moda alanını esas olarak kadınlara bıraktıkları ileri sürülmüştür ama belli tarihsel nedenlerin ne olduğu ve hangi referanslara dayandiğı konusunda bilgi verilmemiştir.

Bununla birlikte Reed'in kapitalizmin genişlemesi ve kitle pazarı ihtiyacının ortaya çıkmasıyla güzellik sektörünün kadın nüfusu hedefleyen, kozmetik ve moda ürünlerini almaya teşvik eden reklam ve benzeri propaganda araçlarına başvurmasına yöne- 
lik eleştirisi haklı bir eleştiridir. Bu doğrultuda kadınların moda ve kozmetik sektörü tarafından metaların pazarlanacağı kitle haline getirilmesi, gerçek ihtiyaçlar yerine suni ihtiyaçların oluşturulması ve bu süreçte kadın vücudunun araçsallaştırılması kabul edilemezdir.

Kapitalist sistem, hem moda ve kozmetik üzerinden güzelliği metalaştırmakta hem de kadınlara başarılı ve mutlu bir yaşama giden yolun bir şeyler almaktan geçtiğini iddia eden propaganda aygıtlarının geliştirilmesine zemin hazırlamaktadır. Bu şekilde kadın sürekli olarak kapitalizmin piyasa güçleri tarafından yönlendirilmekte, kadın kimliği ve yaşam biçimine karmaşık bir şekilde etki etmektedir. Dolayısıyla kadın olmanın ne anlama geldiği kadına dair piyasada oluşturulan imajlar, anlatılar ve kanaatler aracılığıyla sürekli müzakere edilmekte ve yeniden tanımlanmaktadır (Gökarıksel\& McLarney, 2010, s. 4). Bu nedenlerle kapitalizmin kadına dair oluşturduğu imgelerin eleştirilmesi önem taşımaktadır.

"Kadınlığın Gizemi” başlıklı altıncı ve son bölümde ise Betty Friedan’ın The Feminine Mystique /Kadınlığın Gizemi adlı çalışması incelenmektedir. Betty Friedan bu çalışmasında Amerikan toplumunun üst orta katmanlarındaki kadınların durumunu ele almıştır. Bu çerçevede II. Dünya savaşı sonrasında ortaya çıkan "kadının yeri evidir" şeklinde ifade edebileceğimiz anlayışın kadınlar tarafından nasıl sahiplenildiği ve dayatılan "Amerikan Rüyası”nın bu anlayışın oluşmasındaki payının ne olduğu üzerinde odaklanılırken çizilen mutlu ev kadını imajı ile kadınların gerçek durumu arasındaki fark ortaya konmaya çalışılmıştır.

Şunu belirtmek gerekir ki Amerika’da II. Dünya Savaşı süresince oluşan güvensizlik ortamı nedeniyle evliliğe ve aileye verilen önem artmıştır. Yuva ve ev kavramları yüceltilmiştir. Devlet kadının iş hayatındaki varlı̆̆ını savaşs süresince desteklese de bunun geçici bir durum olup kadının asıl yerinin evi olduğunu, çocuk bakımı ve ev işleriyle ilgilenmesi gerektiğini vurgulamıştır. Savaş sonrası yıllarda da Amerikan ailesi geleneksel değerlere bağl1, aile içi rollerin cinsiyete bağlı olarak farklılaşttğ̆ bir ideal olarak resmedilmiştir. Bu dönemde ortaya çıkan ve Friedanın eleştirdiği aile idealinin özellikle kadınlar tarafından benimsenmesinde Soğuk Savaş’ın oluşturmuş olduğu kaygı ve güvensizlik ortamı etkili olmuştur.

Bunlara ek olarak bu dönemde Amerikalılar tasarruflarını bekletmek yerine harcamaları yönünde yönlendirilmiştir. Gelirlerindeki artışa bağlı olarak ve devletin de desteğiyle Amerikalıların tüketimi artmıştır. Dolayısıyla genç insanlar erken yaşta evlenip, evliliklerinin ilk yıllarında çocuk sahibi olup, hoş bir çevrede yaşayıp, araba, çamaşır makinesi, buzdolabı, televizyon seti ve diğer ev aletlerine sahip olmak yönünde teşvik edilmiştir. Bu eşyalara sahip olmanın Amerikan tarzı ve iyi bir yaşamı temsil ettiği kabul edilmiştir. Bu çerçevede ortaya konan kamu politikaları, artan zenginlikle birlikte ortalama alım gücüne sahip tüm beyaz Amerikalılar için yenilik ve hareketlilik taleplerini mümkün kılmıştır. 
1960'lara gelindiğinde ise çeşitli toplumsal hareketler aracılığıyla güvenlik kaygısından bağımsız olarak muhafazakâr âdet, değer ve geleneklerin sorgulanmaya başlad1ğını görmek mümkündür. Aile ve kadının durumu da benzer şekilde bu doğrultuda sorgulanmıştır. 1960'lı yıllarda yaşam maliyetlerinin artmasına bağlı olarak ikinci bir gelir arayışı, doğum kontrolü aracılığıyla doğurganlık üzerinde kontrolün artmış olması, artan eğitim seviyesine bağlı olarak kadınların kendini tatmin için çalışma hayatına katılmak istemesi gibi faktörler Amerikan ailesinin ve kadının dönüşümünde etkili olmuştur. Friedan ve Reed'in dâhil olduğu feminist hareket, önceki dönemde kadının yerinin evi olduğu, ev işleri ve çocukların yetiştirilmesinin kadının asıl sorumluluğu olduğu varsayımını reddetmiştir. Bu karşı koyuş, Amerika'da kendilerini feminist olarak nitelendirmeyen kadınların da ev işi, çocuk bakımı, aile rolleri karşısındaki tutumlarının değişmesinde etkili olmuştur.

Ancak daha önce söylediğimiz gibi feminizm kalkış noktası olarak tepkisel ve muhalif olsa da kullandığı söylem ve talepleri bakımından Batı düşüncesinin karakteristik özelliklerini taşımaktadır. Reed’in Kadın Özgürlüğünün Sorunları kitabında ileri sürdüğü iddiaları da bu çerçevede değerlendirmek mümkündür. Reed, kapitalist sistemi ilerleme ve ekonomik gelişmeyi merkeze koyması, doğal olan bütün kaynakların bu uğurda tüketilmesine neden olduğu ve sosyo-ekonomik hayatta insanı, üretmek-tüketmek döngüsüne sıkıştırdığı için eleştirmemektedir. Tam aksine kitabındaki argümanlarıyla kadını bu döngüye sokma mücadelesi vermektedir. Bu mücadele içerisinde kadını aile ve annelikten "kurtarma" düşüncesi de yer almaktadır. Ancak Reed'in ve temsil ettiği feminizmin gözden kaçırdığı şey, ev ve ailenin kadını sarmalayan ve ona aidiyet duygusu kazandıran önemli sosyolojilerden biri olduğudur.

\section{Kaynakça}

Erdoğan, A. (2011). Erkek Aklına Eklemlenen Feminizm, DÜBAM.

Fraser, N. (2009). Feminism, Capitalism and the Cunning of History, New Left Review 56, March-April, 97-117.

Giddens, A. (2005). Sosyoloji, çev. Ülgen Yıldız Battal, Phoenix Yayınevi, Ankara.

Gökariksel, B \& McLarney, E. (Fall 2010). Muslim Women, Consumer Capitalism, and the Islamic Culture Industry, Journal of Middle East Women's Studies, Volume 6, Number 3. 1-18.

Marshall, G. (2005). Sosyoloji Sözlüğü, çev. Osman Akınhay\& Derya Kömürcü, Bilim ve Sanat Yayınları. 